\title{
İktisat Öğretiminde Deneysel Yöntem: Sınıf Deneyleri ve Uluslararası İktisat Uygulamaları
}

\author{
Experimental Method in Teaching Economics: Classroom Experiments and Its \\ Applications to International Economics
}

Müslüm BASILGAN', Emin ERTÜRK²

\begin{abstract}
ÖZET
Genelde iktisat konuları öğrencilere oldukça soyut düzeyde öğretilmekte ve bu da öğrencilerin iktisat derslerine yönelik tutumlarını olumsuz etkilemektedir. Fakat dersler öğrencilerin kararlar aldığı ve etkileşimde bulunduğu sınıf deneyleri ile tamamlanabilir. Sınıf deneyleri herşeyden önce öğrencileri ekonomik karar vericiler rolüne koyarak önemli iktisadi kavramları kendi kendilerine keşfetme imkanı ve kitaplarda verilen teorilerin uygunluğunu görme fırsatı sunmaktadır. Nitekim yapılan çalışmalar sınıf deneyleri ile öğrencilerin iktisat derslerine daha fazla ilgi gösterdikleri ve sınavlarda daha başarılı olduklarını göstermiştir. Bununla birlikte sınıf deneylerinde uluslararası iktisat kavramlarını yansıtmak mikro iktisadi kavramlarınkinden daha zordur. Sonuç olarak bu alanda çok az deney bulunmaktadır. Bu sınıf deneyleri daha çok karşılaştırmalı üstünlüklerin işleyişi, ticarette uzmanlaşmanın önemi ve döviz kuru üzerine odaklanmıştır. Bu çalışmanın amacı da sınıf deneylerini tanıtmak ve bunun uluslararası iktisat üzerindeki uygulamalarını göstermektir.
\end{abstract}

Anahtar kelimeler: Deneysel iktisat, İktisat Eğitimi, Sınıf Deneyleri, Uluslararası Ticaret, Döviz Kuru

\section{GiRiş}

Sınıf deneyleri "temel iktisadi fikirleri anlamayı kolaylaştırmak için tasarlanan kısa, interaktif uygulamalar" olarak tanımlanabilir (Holt ve McDaniel, 1998: 257). Öğrencilerin derslere sadece bir okuyucu olarak ya da dinleyici olarak katılmak yerine aktif olarak katılmaları durumunda dersleri daha iyi hatırladıkları uzun zamandır eğitimciler tarafından ileri sürülmektedir (Parker, 1995). Iktisatta sınıf deneylerini kullanma fikri Chamberlin'in (1948) "eksik piyasa"lı sınıf deneylerine kadar gitse de, bir çok uygulama son zamanlarda deneysel iktisattaki araştırmacıların sayısındaki artışın bir ürünü olarak ortaya çıkmıştır. Pedagojik araçlar olarak sınıf deneylerinin sistematik kullanımı 1990'larda yaygınlaşmaya başladı. İktisatta sınıf deneylerine artan ilginin önemli nedenlerinden biri deneysel iktisatçıların sayısındaki bir artış olsa da geleneksel ders

\begin{abstract}
In general, economics courses are taught to the students at a fairly abstract level and it has a negative effect on student's attitudes towards economic courses. But the courses can be completed with classroom experiments that students make decisions and interact with. Classroom experiments give the students the opportunity to explore on their own basic economic concepts by putting them in the role of economic decision makers and the chance to see the appropriateness of theories given in the books. Indeed, the studies on classroom experiments showed that with classroom experiments students are more interesded in economic courses and more successful in the exams. However, it is more difficult to reflect international economics concepts in classroom experiments than micro-economic concepts. As a result very few classroom experiments exist in this area. These classroom experiments mostly focused on the operation of comparative advantage, the importance of specialization in trade and exchange rate. The aim of this study is to introduce the classroom experiments and to show its applications on international economics.
\end{abstract}

Keywords: Experimental Economics, Economics Education, Classroom Experiments, International Trade, Exchange Rate.

verme biçimindeki memnuniyetsizlik de bu süreci etkilemiştir. İktisat konuları, özellikle uluslararası iktisat konuları, birçok öğrenci için zor konular olarak görülmektedir. Genelde öğrenciler iktisadı soyut ve gerçekçi olmayan bir bilim olarak görmektedir. Geleneksel ders anlatımında teorik modeller ekonomik davranışı ve piyasa sonuçlarını tahmin etmede ve açıklamada analitik olarak sunulmuş ve uygulanmıştır. Birçok ders kitabı ve dersi veren eğitmen teoriyi yansıtan ve modelleri daha anlamlı yapan örneklere ağılık vermektedir. Fakat çok sayıda öğrenci bu analitik çerçeve ile düşünmenin ve onun anlamlılığını kavramanın zor olduğunu düşünmektedir. Bunun sonucunda iktisat hocaları genellikle "bu teoride doğru fakat..." ile başlayan cümlelerle sık sık karşılaşmaktadırlar.

Aşağıdan yukarıya (bottom-up) katılımcı öğrenme yaklaşımının bir uygulaması olarak sınıf deneyleri birçok iktisadi kavramı gerçekçi kılmakta ve birçok 
öğrencinin ekonomik modelleri daha iyi anlamasına imkân tanımaktadır (King, 1999). Üstelik sınıf deneylerinin öğrencilerin iktisata olan ilgisini ve motivasyonunu yükselttiği kabul edilmektedir (Holt ve McDaniel, 1998). Bergstrom ve Miller (2000: iv), alanda öncü olan kitaplarında, sınıf deneylerinde öğrencilerin alacağı faydayı şöyle açıklamaktadırlar:

"Siz ekonomik durumlarda insanların davranışını ve etkileşimlerini öğreniyor olacaksınız. Ve bu karşılıklı etkileşimde bulunan ekonomik ajanlardan biri olarak, böyle bir ajan tarafından karşı karşıya kalınan problemleri birinci elden tecrübe edebileceksiniz."

Gerçekte günümüzde artık iktisat derslerinde sınıf deneylerinin kullanımına yönelik ilgi artmakta, birçok iktisatçı derslerinde deneyleri aktif olarak kullanmakta ve sınıf deneylerine övgü yağdırmaktadır. Örneğin Holt (1999) "iktisat öğretiminde en heyecan verici gelişmelerden biri öğrencileri doğrudan ele alınan ekonomik çevreye sokan sınıf deneyleri" olduğunu ifade etmiş̧ir. Bu gelişmeleri ders kitaplarının içeriğindeki değişikliklerde ve önemli dergilerde yayınlanan makalelerdeki artıştan da görebiliriz. Giriş derslerindeki ders kitapları (örneğin, Bergstrom ve Miller, 2000) artık sınıf deneylerine odaklanmakta ve bunları ek olarak vermektedir. Journal of Economic Perspectives, Economic Inquiry, the Southern Economic Journal, and the Journal of Economic Education gibi alanla ilgili önemli dergiler deneylerin kullanımını içeren makaleler yayınlamaktadır (Dickie, 2006).

Son yıllarda iktisatta sunulan yaratıcı uygulamalar deneylerin öğretme aracı olarak uygulanabileceği geniş bir alanın varlığını yansıtsa da (Parker, 1995) yapılan sınıf deneyleri daha çok müzayedeler, piyasa dengesi gibi mikro iktisat konularına yönelik olmuştur. Bu nedenle uluslararası iktisat kavramlarını yansıtan sınıf deneyleri çok az bulunmaktadır (Mitchell vd., 2009).

Esas olarak uluslararası iktisat konuları deneysel iktisadın bir yöntemi olan sınıf deneylerine oldukça uygun konulardır. Otarşi ve dış ticaret serbestisinin karşılaştırılması, uluslararası ticaret teorilerinin test edilmesi, döviz kuru davranışının incelenmesi, gümrük tarifesi gibi müdahalelerin etkisini ortaya koyma başta olmak üzere, bir çok konu deneysel yöntem ile incelenebilir ve test edilebilir konulardır. Bu açıdan öğrencilerin klasik ders verme yöntemi ile anlamada zorluk çektikleri temel uluslararası iktisat konularının öğretiminde deneysel iktisat ve bu bağlamda sınıf deneyleri önemli bir araç olarak işlev görebilir. Nitekim bunun fark edilmesiyle uluslararası iktisat alanında bazı sınıf deneyleri yapılmıştır.

Bu çalışmanın amacı da iktisatta yaygın bir şekilde kullanılmaya başlanan sınıf deneylerinin uluslararası iktisat üzerindeki etkisini göstererek, uluslararası iktisat alanında yapılan az sayıdaki deneylerin tasarımı konusunda bilgi vererek ve sınıf deneylerinin başta uluslararası iktisat olmak üzere iktisat derslerinde uygulamasını teşvik ederek literatüre katkı sağlamaktır. Bu amaçla ilk olarak pedagojik bir araç olarak sınıf deneylerinin faydaları ele alınacaktır. İkinci olarak sınıf deneylerinde önemli tartışma konularına yer verilecektir. Üçüncü olarak uluslararası iktisatta yapılan sınıf deneyleri uluslararası ticaret ve döviz kuru deneyleri başlıkları altında ele alınacaktır. Sonuç kısmında genel bir değerlendirme yapılacaktır.

\section{PEDAGOJIKK BIIR ARAÇ OLARAK SINIF DENEYLERININ FAYDALARI}

İktisat öğrencileri genellikle hem alanlarının soyut doğasını hem de gerçek dünya problemlerine ve konularına yönelik uygulama eksikliğini eleştirmektedirler. Bunun da temel nedeni iktisattaki derslerin genellikle teorik temelli olmasıdır. İktisat teorisi derslerde işlenirken oldukça soyut düzeyde kalmaktadır. $\mathrm{Bu}$ problemi ortadan kaldırmak için iktisat konularının öğretme biçiminin geliştirilmesi/zenginleştirilmesi yoluna gidilmiştir. Özellikle iktisat derslerinde kavramların daha iyi anlaşılmasında bir araç olarak farklı piyasa senaryoları ya da bireysel karar verme şartları tasarlayan deneyler kullanılması bir çözüm olarak görülmüştür (Bastian, Menkhaus ve Yakunina, 1996). Bir araştırma yöntemi olarak deneysel iktisadın artan kabulü ile birlikte iktisat eğitiminde oyunların ve deneylerin kullanımında da artış olmuştur (Gremmen ve Potters, 1997).

İtisat alanında sınıf deneylerinde meydana gelen bu gelişmelerle birlikte günümüzde sınıf deneylerinin önemli faydaları olduğu artık kabul edilmiş durumdadır. Bu faydalar özellikle sınıf deneyi ile elde edilen tecrübe ve öğrenme eksenindedir. Piyasa mekanizmasını açıklamak için tarihsel olarak tercih edilmiş olan eğitmen-merkezli derse güvenmek yerine sınıflarda deneylerin kullanımı öğrencilere tecrübeye dayalı öğrenme fırsatı sağlayarak onların kontrollü bir piyasa çevresine katılma şansı ve normal olarak sadece bir grafik üzerinde tanımlanan ve açıklanan piyasa güçlerini gözleme imkânı vermiştir (Emerson ve Toylor, 2004). Bu nedenle sınıf deneyleri her şeyden önce öğrencileri ekonomik karar vericiler rolüne koymaktadır. Holt $(1999$, s.1) tarafından da belirtildiği üzere sınıf deneyleri "öğrencileri ele aldıkları ekonomik ortamın içine doğrudan yerleştirmektedir". Birçok iktisat öğrencisi piyasanın talep boyutu açısından olmasa da özellikle arz boyutu açısından çok az ekonomik karar verme tecrübesine sahiptir. Çoğu katıldıkları ve derslerde gördükleri piyasanın gerçekte nasıl işlediği 
konusunu düşünmemişlerdir bile. Bu noktada sınıflarda tasarlanan deneysel ortam öğrencilere bir alıcl, satıcı, üretici, başka bir ülkeden mal alan, başka bir ülkeye mal satan, gümrük vergisi veren, döviz alan, ya da farklı bir role girmesine imkân tanıyarak verilen kararları doğrudan yansıtmaktadır. Örneğin bir piyasa oyununda bir tüccar olmak öğrencilere rekabetin dengeleyici gücünü tecrübe etmeye olanak tanımakta, bir kamu oyununda yer alma öğrenciye bireysel rasyonalite ve toplumsal etkinlik arasındaki potansiyel çatışmaları göstermekte, bu oyunda bir hükümet rolü de öğrencilere farklı ticaret olasılıkları ve parasal ve mali politikaların uluslararası yankılarını öğretmektedir (Gremmen ve Potters, 1997).

Gerçekten eğitim literatüründeki araştırmacılar öğrencilerin deneysel ya da aktif öğrenme ile daha iyi öğrendiklerini göstermiştir (Kolb, 1984). Sınıflarında deneyi kullanan araştırmacılar da sınıf deneylerin iktisadın temel ilkelerini yansıtmada güçlü bir yöntem olduğunu kabul etmişlerdir (King, 1999). Bir sınıf deneyinde öğrencilere kontrollü bir çevrede ekonomik kararlar alması istenmektedir. İyi tasarlandığında ve uygulandığında deneyler öğrencilerin kendi kendilerine önemli kavramları keşfetmelerine hizmet etmektedir. Bu keşif öğrencilerin yeni bulunan bilgiyi büyük ölçüde sahiplenmelerine götürmektedir (Emerson ve Hazlett, 2012).

Bu fikirler öğrencilerin deneyler ile daha fazla öğrenebileceklerini ortaya koyan çalışmalar ile daha da pekişmiştir. Örneğin Frank (1997) yalnızca deneyi ve sonuçlarını izlemenin bile öğrenme üzerinde etkili olduğunu göstermek için bir sınıf deneyi gerçekleştirdi. Kamu finansmanı dersinde yapılan bu deneyde "kamusal mülkiyet trajedisi" konusu normal ders yöntemi ve sınıf deneyi yöntemi ile verildi. Daha sonra kontrol grubundaki öğrenciler (normal ders yöntemi ile dersi alanlar) konuyla ilgili bir testi cevaplandırdılar. Aynı sorular sınıf deneyine katılan ve sınıf deneyini izleyen diğer öğrenciler tarafından da cevaplandırıldı. Çalışmada deneysel grupta yer alan öğrencilerin vermiş olduğu doğru cevapların oranı kontrol grubundakilerden oldukça yüksek çıktı. Deneysel grup içinde de deneyde aktif olarak rol oynayan kişilerin puanları sadece deneyi seyredenlerin puanına göre yüksek çıktı. Gremmen ve Potters (1997) sınıf deneylerinin objektif etkisini ortaya koymak için bir çalışma yaptı. Çalışmada iktisadi kavramların dinamik ve karşılıklı bağımlı bir dünyada tanımlanan belirli bir model ile nasıl ilişkilendirilir? sorusu ele alındı. Bunu ortaya koymak için SIER (Simulating International Economic Relations) oyunun uygulandığı ders verme yöntemi geleneksel ders verme yöntemi ile karşılaştırıldı. Bu amaçla seçilen üç sınıfta öğrenciler SIER oyunu ile konunun anlatıldığı oyun grubu ve geleneksel ders verme yöntemi ile konunun anlatıldığı ders grubu şeklinde ikiye ayrıldı. Üç saatlik ders periyotlarından önce ve sonra yapılan sınavların sonucu oyun grubunun ders grubu ile karşılaştırıldığında önemli şekilde daha çok öğrendiğini ortaya koydu. Emerson ve Taylor (2004) mikro iktisadın ilkelerini öğretmede geleneksel ders verme yöntemine alternatif olarak sınıf deneyleri kullanımının etkisini inceledi. Bu iki yöntemi karşılaştırmak için bahar döneminde verilen dokuz bölümden ikisi deneysel yöntem yedisi geleneksel ders verme yöntemi ile verildi. 300 öğrencinin kullanıldığı çalışmanın sonunda deneysel bir yaklaşımı kullanılarak eğitilen öğrencilerin (deney grubu) geleneksel ders verme yaklaşımı ile eğitilen öğrencilere (kontrol grubu) göre TUCE (Test of Understanding in College Economics) puanında önemli ilerlemeler gösterdiği tespit edildi. Dickie (2006) sınıf deneylerinin ve deneydeki başarı ve katılımcıyı ödüllendiren not teşviklerinin mikro iktisat öğrenimini etkileyip etkilemediğini test etmek için bir deney yaptı. Bahar dönemi boyunca verdiği mikro iktisat dersinin üç bölümüne katılan öğrenciler çalışmanın deneklerini oluşturdu. Sınıfta verilen bölümlerin ikisi deneysel bölümler olarak alındı ve 15 haftalık dönem boyunca toplam yedi sınıf deneyi yapıldı. Üçüncü bölümde (kontrol bölümü) ise geleneksel ders verme yöntemi kullanıldı. Çalışmada sınıf deneyi kullanımının TUCE puanında önemli ilerleme getirdiği tespit edildi. Durham vd. (2007) tarafından yapılan çalışmada sınıfta iktisat deneylerini kullanmanın etkinliği mikro iktisatın ilkeleri ve makro iktisadın ilkeleri derslerinde öğrencilerin başarısı, öğrencilerin iktisada tutumları ve ekonomik bilginin akılda tutulması bağlamında ele alındı. Sonuçlar sınıf deneylerinin açıklamayı tasarladığı konuları kapsayan sorular üzerinde öğrenci başarısının arttırdığını, öğrencilerin iktisatta yönelik tutumunu önemli ölçüde geliştirdiğini ve ele alınan konularla ilgili olarak öğrencilerin daha fazla bilgiyi akılda tuttuğunu gösterdi.

Sınıf deneylerinin önemli bir başka faydası öğrencilerin sınıf deneylerine aktif olarak katılmaktan zevk almaları ve bunun eğitmene olan tutumlarında pozitif etki yaratmasıdır. Sınıf deneyleri ile konuları işlemek öğrencileri normal sınıf düzenine göre daha farklı bir düzene göre yerleştirmek ve onlara aktif bir rol vermek anlamına geldiğinden öğrencilerin deneylerden elde ettikleri bilgileri daha kolay hatırlamasını sağlayarak dersten zevk almalarını artırmaktadır (Parker, 1995). Ortmann ve Colander (1997) deneylerin öğrencileri daha memnun ettiğini ve daha çabuk kavramasını sağladığını belirtti. King (1999) yaptığı deney sonrası anketlerde öğrencilerin deneylerden - öğrenme sürecine doğrudan katılmadan- zevk al- 
dıklarını gördü. Parker (1995) deneylerin öğrencilerin zevkini artırarak iktisat derslerinin "cazibesini" değiştirebileceğini belirtti. Houston ve Hoyt (2001) yaptığı sınıf deneyi sonucunda öğrencilerin heyecanlarını ve konuya ilgilerinin arttığını tespit etti. Mason (2001) iktisat derslerinde deneylerin hem öğrencileri daha ilgili hale getirdiğini hem de sunumu neşeli hale getirdiğini gözlemledi.

Sınıf deneylerinin eğitmen açısından da önemli faydaları bulunmaktadır (Tisha Emerson ve Denise Hazlett, 2012; Parker, 1995). Birçok araştırmacı eğitmenlerin deneyleri kullanmakta zevk aldıklarını vurgulamışlardır. Örneğin, Brauer ve Delemeester (2001) eğitimcilerin de öğrenciler gibi teorik anlatımdan ziyade deneylerden zevk aldığını ve bu nedenle sınıf deneylerinin onlara çekici geldiğini savundu. Benzer şekilde bazı iktisadi kavramları sınıf deneyleri ile öğretmede elde ettiği olumlu sonuçların bu kavramları öğrencilere sunmada kendine olan güvenin arttığını belirtten Holt (1999: 609) deneysel uygulamaların getirdiği zevki şu cümlelerle ifade etti:

"Son olarak bu uygulamaların eğitmenin kendi anlayışını ve temel ekonomik ilkelere güven duymayı pekiştirme şeklinde zor ama son derece değerli bir amaca hizmet ettiğine inanıyorum. Bu, haklı olarak, lisans-yüksek lisans programlarında teknik, piyasaların etkinliği ve birçok piyasa dışı dağıtım mekanizmaları gibi şeyler için iyi bir his geliştirmede zaman tasarruf edeceği için önemlidir. Deneyleri derslerime dahil etmeye başladığımdan itibaren öğrettiğim şeyle ilgili kendi güvenim önemli ölçüde artmıştır. Ve öncesine göre öğretmekten daha çok zevk alıyorum".

Son olarak sınıf deneylerinde standart bir uygulama olarak kabul edilen deney sonrası tartışma soruları ile öğrenciler konuları derinlemesine tartışarak deneyde karşılaştıkları süreçleri görme ve kendi kararlarını karşılaştırma imkânı elde etmektedir. Deney sonrası tartışmalar başka tartışma alanlarına geçmeyi de getirmektedir. Örneğin piyasa deneylerinde bir kişinin elde ettiği sonuçtan memnun olmaması durumunda tartışma aile arka planına ya da yoksul bir duruma kadar gidilebilir (King, 1999). Tartışma soruları ile her öğrenci sadece deneye katılmakla kalmaz deneyin sonuçlarını yorumlamada elde ettiği iktisat teorisi bilgisini kullanarak bir analist olarak rol oynamaktadır (Parker1995).

Sınıf deneylerinin bu avantajlarına karşın bazı potansiyel dezavantajları-maliyetleri- de bulunmaktadır. King'e (1999) göre bu maliyetler şunlardır: 1. Sınıf deneylerinin ders zamanını alması. 2. Deney süresince hesaplamalar yapma, grafikler oluşturma ve malzemeyi dersle birleştirme zaman aldığından deneyleri yapmak için ekstra zamana ihtiyaç duyma. 3. Bazı öğ- rencilerin, kişilik özellikleri ve kargaşa ve koşuşturmacayı sevmeme nedeniyle, deneye ilgi duymamaları. 4 . Bazı eğitmenlerin sınıf deneylerini, özellikle deneyde kontrolü kaybetme nedeniyle, yönetilmesi zor bir yöntem olarak görebilmeleri ve 5 . Öğrencilere para gibi teşvik vermeyi gerektirmesi.

Bu dezavantajlarına karşın sınıf deneylerinin yukarıda verilen etkin öğrenme ve öğretme yararları dikkate alındığında deneysel öğretmeyi geliştirmek gerektiği açık biçimde ortaya çıkmaktadır.

\section{SINIF DENEYLERINDE ÖNEMLI NOKTALAR}

Pedagojik bir araç olarak sınıf deneylerinin yukarda belirtilen faydaları yanında bazı tartışma konuları da ortaya çıkmıştır. Bu açıdan sınıf deneylerinde tartışılan üç önemli konu bulunmaktadır. Bunlar sınıf büyüklüğü (deneylerin kaç kişilik sınıflarda yapılacağı), sınıf deneylerinin hangi zamanda yapılacağı ve öğrencilere deneye katılmalarından dolayı verilen teşviklerdir.

\subsection{Sınıf Büyüklüğünün Etkisi}

Büyük sınıflarda deney yürütmek daha zor olduğundan yapılan deneylerin büyük kısmı göreli olarak küçük sınıflarda uygulanmıştır (DeYoung, 1993). Deneyler tüm öğrencilerin görebilmesinde sorun yoksa sınıfın önünde yapılabilir. Fakat özellikle öğrencilerin birbirinin etrafında dolaştığı ve müzakerelerde bulunduğu mal ticareti gibi deneylerde öğrenci sayısının maksimum 40 olması önerilirken sözlü çift müzayede deneyi gibi kendi yerlerinde kalan öğrencilerin olduğu deneylerin daha kalabalık sınıflarda yapılması önerilmektedir (King, 1999).

\subsection{Sınıf Deneylerinin Hangi Zamanda Yapılacağı}

Sınıf deneylerinin ne zaman yapılması gerektiği önemli bir konu olsa da (King, 1999) bu konuda bir görüş birliği bulunmamaktadır. Örneğin DeYoung (1993) sınıf deneylerinin sınıfın ilk başlarında öğrencilerin henüz teorik bilgiye sahip olmadıkları zamanda yapılmasını önermiştir. Bu öneri Noussair ve Walker (1998: 67) tarafından desteklenmiştir. Yazarlara göre ilgili teoriye gitmeden önce bir deney yapma öğrencilere kendi kendilerine teoriyi keşfetmesine imkân tanımakta ve onların teorinin belirttiği belirli bir eylemi takip etmesini engellemektedir. Bu düşüncelerin aksine Bergstrom ve Miller (2000) deney öncesinde bazı örnekler ile öğrencilerin iyi hazırlanmasını önerirken, King (1999), ortada bir yol seçerek, öğrencilerin bazı kavramları (örneğin, fayda maksimizasyonu) öğrenmeleri fakat temel meseleler konusunda (piyasa dengesi) bilgiye sahip olmamaları gerektiğini önermektedir. 


\section{3. Öğrencilere Deneye Katılmalarından Dola- yı Verilen Teşvikler}

Sınıf deneylerinde önemli bir risk öğrencilerin seçimlerini net olmayan sonuçlar meydana getirecek şekilde rassal olarak yapabilmeleridir. Bu nedenle sınıf deneylerinde önemli bir sorun öğrencilerin gerçek dünyadaki gibi davranmaları için nasıl teşvik edileceğidir (Emerson ve Hazlett, 2012). Sınıf deneylerinde öğrencilere verilecek teşviğin cinsi, miktarı vb. konularda farklı uygulamalar, (örneğin, Hazlett (1997) teşvik aracı olarak çikolata kullanırken, Haupert (1996) ekstra not, Parker (1995) yemek kullanmıştır) bulunsa da tartışma daha çok iki konu üzerinde devam etmektedir. Birincisi; paranın teşvik aracı olarak kullanılıp kullanılmaması, ikincisi de; ekstra notun teşvik aracı olarak kullanılıp kullanılmamasıdır. Paranın teşvik aracı olarak kullanılması konusunda önemli bir fikir Holt tarafından getirilmiştir. Holt (1999)'a göre öğrencilerin doğal rekabetçiliği onları başarmaya güdülediğinden dolayı herhangi bir parasal teşviğe gerek bulunmamaktadır. Fakat King (1999) öğrencilerini motive etmek için çok az bir paranın uygun olacağını düşünmektedir. Ekstra notun kullanımı ile ilgili olarak ortaya çıkan eğilime baktığımızda da ekstra notun bir teşvik aracı olarak kullanılmaması yönünde fikirler ağırık kazanmaktadır. Bunda en önemli etken, ekstra not öğrencilere deneycinin uyarıcı hedeflerine yönelik bazı motivasyonlar verse de, genel not sistemini bozmadan öğrencileri motive edecek şekilde yeterli bir not vermenin zor olmasıdır (Parker, 1995). Bu nedenle örneğin, King (1999) ekstra notun teşvik olarak verilmemesi gerektiğini belirtirken, Dickie (2006) deneysel piyasadaki başarıyı ödüllendiren not teşvikinin sınıf deneylerinin faydalı etkileri üzerinde negatif bir etki doğurduğunu ortaya çıkardı.

Bu tartışmalara karşın deneylerde, hangi çeşit ödül kullanılırsa kullanılsın, küçük ve rassal olarak seçilen bir ödülün deneyde gürültüyü azalttığı (Holt, 1999) ve öğrencilerin deney boyunca ilgisini ve deneyin amaçlarına odaklanmayı sürdürmesine yardım ettiği kabul edilmektedir (Mitchell vd., 2009).

\section{ULUSLARARASI IKTISATTA SINIF DENEYLERI}

Sınıf deneylerinde uluslararası iktisat kavramlarını yansıtmak mikro iktisadi kavramlarınkinden daha zor olduğundan bu alanda çok az deney bulunmaktadır (Mitchell vd., 2009). Bu kısıtı göz önünde bulundurarak yapılan sınıf deneylerini uluslararası ticaret ve döviz kuru başlıkları altında ele alacağız.

\subsection{Uluslararası Ticaret Deneyleri}

Literatür incelendiğinde uluslararası ticaret alanında yapılan ilk deneylerin (Stodder, 1994; Haupert,
1996; Houston ve Hoyt, 2001; Mason, 2001) karşılaştırmalı üstünlükler teorisine yönelik olduğu görülmektedir. Hatta uluslararası iktisatta sınıf deneylerinin genel olarak karşılaştırmalı üstünlüklerin işleyişi üzerine odaklandığını söylemek yanlış olmaz. Bu yoğunlaşmanın en önemli nedenlerinden biri karşılaştırmalı üstünlükler kavramının "uzmanlaşmanın ilkelerini, iş bölümü ve mübadelenin temelini oluşturan, iktisat teorisinin en önemli kavramlarından biri" olması (Haupert, 1996: 37) ve karşılaştırmalı üstünlükler kavramının kendisinin, gerçek dünyada kolay uygulamaya elverişli olmamasından dolayı, öğrenciler tarafından tam olarak anlaşılamamasıdır.

Karşılaştırmalı üstünlükler teorisi öğrencilerin uluslararası iktisat derslerinde karşılaştığı ilk konulardan biridir. Üstelik toplum üyelerinin uzmanlaşmadan ve ticaretten fayda elde ettikleri şeklindeki Ricardocu fikir iktisatta en güçlü fikirlerden biri olarak kabul edilmektedir. Karşılaştırmalı üstünlükler teorisine göre bir tarafın diğerlerine göre üretimde "mutlak" etkinliğe sahip olsa bile uzmanlaşma ve serbest ticaret tüm taraflara fayda getirecektir (Anderson vd., 2008). Bu nedenle karşılaştırmalı üstünlükler teorisi ülkelerin fırsat maliyetleri düşük olan faaliyetlerde uzmanlaşmadan kazanç elde edebileceğini belirtmektedir. Öğrencilere, uzmanlaşma ve ticaret hadlerinden kazançlar fikrinin iyi derecede öğretilmeden, düşük fırsat maliyetli faaliyetlerde uzmanlaşmaya gidilmesinin anlatılması oldukça güçtür (Chiang, 2007). Bunun sonucunda, karşılaştırmalı üstünlükler ilkesinin uygulamalı sayısal öneklerinin oldukça fazla olmasına karşın, birçok öğrenci kavramın temel dayanağını ve yaygın uygulanabilirliğini anlamada zorluk çekmektedir. Bu zorluğu alanda sınıf deneylerini ilk uygulayanlardan biri olan Haupert (1996: 37) şöyle ifade etmiştir: "Kişisel tecrübeler göstermiş ki ne kadar sık Robinson Crusoe hikayesini tekrarlasam ya da öğrencilerime karşılaştırmalı üstünlükleri hesaplama şeklinde ev ödevleri problemleri çözdürsem de kavramın gerçekliği-realitesi- asla onların tümünün kafasına tam girmemiştir".

Karşılaştımralı üstünlükler teorisinin anlaşılmasındaki bu güçlükler nedeniyle teorinin temel unsurlarını aydınlatacak bazı interaktif sınıf deneyleri yapılmıştır. Haupert (1996) uluslararası ticareti iktisat müfredatında en önemli fakat yanlış anlaşılan bir konu olarak tanımlayarak öğrencilerin uluslararası ticaret sürecini ve karşılaştırmalı üstünlükler teorisini daha iyi anlamaları için bir dizi sınıf deneyi uyguladı. Deney öğrencilerin tüketim amaçlarını onlara karşılaştırmalı bir üstünlüğe sahip olmasını sağlayacak şekilde sadece malların üretiminde uzmanlaşarak ve daha sonra diğer oyuncular ile ticaret yaparak gerçekleştirebilecekleri şekilde tasarlandı. Deneyin amacı fırsat 
maliyeti ve karşılaştırmalı üstünlükleri yansıtmak olduğundan iki mal ve dört oyuncu seçildi. Her oyuncu A1, A2, B1 ya da B2 tiplerinden biri olarak belirlendi. Dört tip oyuncudan her birine bir birim çelik ya da bir birim buğday üretmek için kaç saat emek gerektiği söylenerek bir miktar emek saati ve üretim fonksiyonu tahsis edildi. Dağıtılan emek saatleri sayısı ve her bir malı üretmek için gerekli saat sayısı yapılan beş raunt süresince sabit tutuldu. 1. tip oyuncuların her birine 80 emek saati 2. tip oyuncuların her birine 150 emek saati tahsis edildi. Sonuç olarak; A tipi oyuncular (A1 ve $A 2$ ) buğday üretmek için bir saat emeğe ve B tipi oyuncular (B1 ve B2) çelik üretmek için bir saat emeğe ihtiyaç duyarken $A 1$ oyuncular çelik üretmek için iki saat emeğe ve $A 2$ oyuncular üç saat emeğe intiyaç duymaktaydılar. B1 oyuncular buğday üretmek için iki saat emeğe gerek duyarken B2 oyuncular üç saat emeğe gerek duymuşlardı. Oyuncular, her birinin sınırlı miktarda sahip olduğu emek saatleri veri iken, kaç birim buğday ve çelik üreteceklerine karar vermek durumundaydılar. Deneyde oyuncular bir malın herhangi bir kesirli birimi şeklinde üretim yapamadıkları gibi emek saatlerini de kesirli biçimde kullanamıyorlardı. Ayrıca hem emeğin hem de üretim mallarının bir periyottan diğerine geçme imkânı söz konusu değildi.

Bu deneyde, her öğrenci veri bir girdi tipi ile sadece iki mal üretme kapasitesine sahip olduğundan, bir malı üretmenin fırsat maliyeti üretilebilecek diğer mal miktarı olarak alınmıştır. Deneydeki tüm katılımcılar aynı girdi düzeyleri kullanarak aynı iki ürünü ürettiğinden karşılaştırmalı üstünlükleri belirlemek için oyuncular arasında üretim olasılıklarını karşılaştırma da kolaylaşmıştır.

Haupert (1996) tarafindan tasarlanan bu deney 5 raunt şeklinde yürütülmüştür. Her rauntta kurallar belli parametreler ortaya çıkaracak şekilde değiştirilmiştir. Birinci rauntta bireysel oyuncular arzuladıkları gibi bir buğday ve çelik bileşimini üretme olanağına sahiptiler. Birinci raunttun en önemli özelliği ticaretin söz konusu olmaması ve bu nedenle üretilenin tüketilmesiydi. İkinci rauntta oyuncular tekrar üretim kombinasyonlarını belirleyebilmekte fakat bu kez oyuncular üretim kararlarını verdikten sonra piyasaya girebilmekte ve istedikleri herhangi biriyle ticarete girebilmekteydiler. Bu aşamada buğday ve çeliğin ticareti mümkünken emeğin ticareti yapılamiyordu. Bu rauntta bir oyuncu ticarette bir mal aldığında o malı tekrar ticarete konu yapamıyordu ve onu tüketmesi gerekiyordu. Üçüncü ve dördüncü rauntlarda oyuncular tekrar ticaret yapabiliyorlardı fakat bu kez üretmeden önce taahhüt edilen üretimi ve ticaret anlaşmasının gereklerini yerine getirmek için diğer oyuncular ile görüşme imkânına sahiptiler. İstemeleri durumunda pazarlık ve görüşme sürecinin parçası olarak diğer oyunculara emek dağılımlarını ve üretim fonksiyonlarını açığa çıkarabiliyorlardı. Bu yolla oyuncular üretim planlarını diğer oyuncular ile karşılaştırmalı üstünlükler üzerine temellendirebilme avantajına sahip olmuşlardır. Beşinci rauntta, dördüncü raunttaki üretim ve ticaret kurallarının geçerliliği korunurken, buğday üzerine bir tarife konuldu. Böylece tarife ile birlikte piyasalar serbestçe işletilmediği zaman bunun ticaret ve etkinlik üzerindeki etkisi ortaya konularak karşılaştırmalı üstünlüğe diğer bir boyut eklenmiş oldu. Bu durumda ticarette buğday alan herhangi biri aldığı tüm buğdayın \% 10'una denk bir tarife ödemesi yapmak zorunda olmuştur.

Deneyde birçok öğrencinin birinci ve ikinci rauntta her iki malı üretmeye çalıştıkları görüldü. Bu iki üretim raundun sonunda genel olarak tüm öğrenciler ticaret piyasasına girer girmez diğer öğrencilerin ne üretebileceklerini görme imkânına kavuşurlarken karşılaştırmalı üstünlükler ilkesinin hala farkına varmamış olan öğrenciler de üretimde uzmanlaşmanın ve diğerleri ile ticaret yapmanın avantajları konusunda fikirlere sahip olmaya başladılar. Buna karşın deneyde tüm öğrenciler bu sonuca ulaşmadılar. Öğrencilerin yarısı, karşılaştırmalı üstünlükler teorisi ile ilgili daha önce verilen teorik derslere rağmen, üçüncü rauntta tam uzmanlaşmaya gitmediler ve sonuç olarak tüketim amaçlarına kavuşmadılar. Problemi kavrayanlar ise potansiyel bir ticaret partneri aramış, son üç rauntta üretimlerinde uzmanlaşmaya gitmiş ve karşılaştırmalı üstünlüğe sahip malların ticaretini yapma yolunu seçmişlerdir.

Uluslararası iktisatta ilk sınıf deneylerinden birini gerçekleştiren Stodder (1994) karşılaştırmalı üstünlükleri yansıtan basit bir deney tasarladı. Oldukça kısa olan bu çalışmada Stodder bir ülkenin tüm malların üretiminde mutlak bir üstünlüğe sahip olmasına rağmen ticaretten kazançların var olabileceğini göstermek için öğrencileri ABD ve Meksika'yı temsil edecek şekilde ikiye ayırdı. Mal çeşidi olarak da kamyon (trucks) ve bilgisayar seçildi. Üretim olanakları eğrisinin ne olduğunu açıkladıktan sonra her öğrenciye kendi ülkelerinin üretim olanakları eğrisini kapsayan bir grafik verildi ve öğrencilerden üretim olanakları eğrisi boyunca arzuladıkları bir noktayı - otarşide en iyi üretim ve tüketim noktası - seçmeleri istendi. Daha sonra her birinden her ülkeyi başlangıç "en iyi noktaları"ndan daha iyi yapan kamyon ve bilgisayar içeren bir ticaret noktası bulmaları istendi. Burada "daha iyi" bir ülkenin otarşi ile karşılaştırıldığında her bir maldan daha az ve en azında bir maldan daha fazla elde ettikleri duruma karşılık gelmekteydi. Bu sınıf 
deneyi iki birinci sınıf ve bir yüksek lisans sınıfı olmak üzere toplam üç sınıfta gerçekleşti. Deney sırasında $A B D$ rolü onayan öğrencilerin "beni nasıl daha iyi duruma getirebilirsin ki? Her ikisini de daha iyi yapabiliyorum" şeklindeki soruları karşılaştırmalı üstünlüğün açıklanmaya ihtiyacı olduğunu gösteren sorulardı. Bu sorular karşısında Stodder (1994), karşılaştırmalı üstünlüklerin önemini ortaya koymak için, öğrencilerin ülkenin her iki boyutta da diğerinden "büyük" olması şeklinde "birinci-derece" farklıklara bakmak yerine Meksika'da kamyonların, bilgisayarlar ile karşılaştırıldığında, daha ucuz olduğu şeklindeki ikinci-derece" farklııklara bakması gerektiğini vurguladı. Deneyde Meksika'nın kamyon üretiminde ABD'nin bilgisayar üretiminde tamamıla uzmanlaşarak ticaretten kazançlı çıkabileceği görüldü. Yazara göre bu sınıf deneyi gelişmiş ülkelerin ticaretten elde ettikleri kazanç miktarının ekonomilerin büyüklüğü ile ters orantılı olması gerçeğini yansıtmak için de kullanılabilir.

Chiang (2007) otarşi dengesi, uzmanlaşmadan (ticaretten) toplam kazançlar, minimum ticaret haddi (değişim oranı), nihai ticaret haddi ve uzmanlaşmadan (ticaretten) bireysel kazanç şeklinde karşılaştırmalı üstünlükler teorisinin önemli unsurlarını aydınlatacak interaktif bir sınıf oyunu tasarladı. Oyunun önemi uzmanlaşma ile elde edilecek kazançların diğer firmaların üretim fonksiyonlarını tahmin etmeye ve mevcut bilgi temelinde ticaret hadleri pazarlıklarına (negotiating the terms of trade) bağlı olmasıydı. Oyun çok küçük ve tam rekabetçi firmaların olduğu bir piyasayı temel almaktaydı. Sınıftaki her öğrenci bir firmayı temsil etmekteydi ve bu firmalar öğrencilerin dönem ödevlerini biçimlendirme ve düzeltme şeklinde iki iş yapmaktaydı. Deneyde verilen hizmetin kalitesi açısından firmalar arasında fark bulunmamaktaydı. Hizmetin parasal karşılığı olarak 24 sayfalık bir metin için 100 \$ şeklinde standart bir fiyatlama uygulandı. Oyunda üniversiteye (deneyi yapan kişiye) istikrarlı kaliteyi sağlamak için hem firmaları hem de fiyatı (tüm firmalar için aynı olan) kontrol etme rolü verilmişti. Firmalar arasındaki fark firmaların kalite standardında yaptığı biçimlendirme ve düzeltmelerin oranına bağlıydı.

Deneyde dönem projesi şeklinde standart bir çaIışmanın 240 sayfalık bir metinden oluştuğu ve bunun fiyatının 1000 \$ olduğu ve Ricardocu model ile tutarlı olacak şekilde ölçeğe göre sabit getirili olduğu varsayıldı. Oyun öncesinde her öğrenciye, öğrencinin kendisine ait özel verimlilik oranları dahil, oyun hakkında detaylı bilgi veren bir el broşürü dağıtıldı. Burada verimlilik oranlarının gizli tutulması diğer firmalar ile müzakerede büyük kazançlara yol açma fırsatı verdiğinden dolayı bilginin gizliliğinin önemi öğrencile- re vurgulandı. Oyunda her bir firmayı ayrı ayrı temsil eden 18 öğrenci kullanıldı. Çalışmada 18 firmanın (öğrenciye) her birine rassal olarak tahsis edilen bir verimlilik oranı listesi oluşturuldu. Bu listede ayrıca her projeyi tamamlamak için otarşi (uzmanlaşmanın olmadığı) saatlerinin sayısı ve uygun saatlik ücret oranı (öğrencinin kendi otarşi ücret oranını hesaplamasını yapması için) gösterildi.

Oyunda temel amaç diğer firmalar ile müzakerelerde bulunarak, her firmanın iki görevden (biçim ya da düzeltme) birinde tam olarak uzmanlaşma temelinde, karşılıklı fayda sağlayacak bir iş ortaklığını oluşturmaktı. Bu oyunun ilginç bir yönü hiçbir firmanın önceden belirlenmiş karşılaştırmalı bir üstünlüğe sahip olmamasıydı. Bunun yerine karşılaştırmalı üstünlük potansiyel iş ortağı tarafından belirlenmekte ve bu gerçekte değişebilmekteydi. Örneğin, bir firma başka bir firma ile karşılaştırıldığında biçimlendirmede göreli olarak daha iyi olabilirken diğer firma ile karşılaştırıldığında düzeltmede daha iyi olabilir. Bu nedenle öğrencilerin bunu anlamaları ve diğer tüm potansiyel iş ortakları ile aynı aktiviteyi müzakere etmek için kendilerini sınırlandırmamaları önemliydi. Çalışma bize tarafların daha fazla kazanç elde etmesinin kendisinden çok farklı bir beceriye sahip bir iş ortağını bularak, diğer bir ifade ile uzmanlaşmaya giderek, gerçekleştirilebileceğini gösterdi. Çalışma üstelik güçlü pazarlık becerilerinin ve firmanın kendi verimlilik oranı ve aynı zamanda pazarlık süresince diğer firmalardan öğrenilen bilgiyi saklama yeteneğinin, pazarlık için fazla kazanca sahip olmasa bile, başarılı bir sonuca yol açabileceğini gösterdi. Kısaca bir firma iki görevi tam olarak gerçekleştirmesi durumunda başarılı bir sonuca ulaşabilir. Bunlardan birincisi; en büyük toplam kazanç elde edebileceği bir iş ortağını bulma, ikincisi; daha fazla kazancı zorunlu olarak yaratmayan bir iş ortağı fakat daha fazla kazanç elde etmesine imkân tanıyan daha zayıf bir müzakereci bulma olmuştur.

Houston ve Hoyt (2001) hem ticaretten kazançları hem de bir değişim aracı olarak paranın önemini ortaya koymak için bir sınıf deneyi tasarladı. Deneyde spor ve eğlence aktivitelerine yönelik hayali giriş biletleri kullanıldı. Bu biletler çekicilik özelliği dikkate alınarak belirlendi. Bu açıdan biletler çekicilik düzeyi yüksek olanlar (popüler müzik grupları, popüler spor olayları vb.), belirli öğrenciler için çekici olanlar (kültürel olaylar) ve çok az çekiciliğe sahip olanlar (popüler olmayan Tv gösterileri ya da müzik grupları vb.) şeklinde tasarlandı. Deneyin başlangıcında sınıf iki farklı ülkeyi (Erkekler ve Kadınlar ülkesi) temsil edecek şekilde iki alt gruba ayrıldı. Daha sonra biletler sınıfa dağıtıldı. Bu dağıtımdan önce biletler erkekler için ve kadınlar için cazip olan aktiviteler şeklinde ayrıldı. Bi- 
letler dağıtılırken erkeklere daha çekici olabilen biletlerin kadınlara verilmesine, ya da tersi şeklinde olmaSı, dikkat edilmiştir. Deney toplam dört raunt şeklinde tasarlandı. Birinci rauntta biletler dağıtıldıktan hemen sonra öğrencilere "bu bileti sokakta bir bilet karaborsacısından satın almak zorunda olsaydınız ödeyebileceğiniz ya da istekli olabileceğiniz miktar nedir ?" diye soruldu. Verilen cevapların sonunda biletlerin toplam değeri kayd edildi. İkinci rauntta öğrencilere kendi ülkesindeki herhangi biri ile ticaret yapabilecekleri söylendi. Ticaret tamamlandığında öğrencilere tekrar şu an sahip oldukları bilet için ödeyebilecekleri ve istekli olabilecekleri miktar soruldu. Biletlerin toplam değeri tekrar kayd edildi. Bu raunt ile öğrencilere her ulusun, bireylerin sadece ürettikleri şeyi tüketmesini gerektirmeyecek şekilde, ticaretten kazanç elde etmiş oldukları gösterildi. Üçüncü raunt her iki ulusun uluslararası ticarette önemli kazançlar elde edebildiklerini göstermek için tasarlandı. Burada devlet olarak görev yapan eğitmen öğrenciler (ülkeler) arasındaki engelli kaldırarak birbiri ile ticarette girmelerine izin verdi. Böylece Kadınlar ülkesindeki vatandaşlar ile Erkekler ülkesindeki vatandaşlar birbiri ile serbestçe ticaret yapabilir duruma geldi. Burada biletlerin sayısı ya da dünyada üretilen biletlerin niteliğinde bir atış olmaksızın biletleri daha yüksek değerlendiren insanların ellerine ulaşmasına imkân tanındı. Bu aşamada kaçınılmaz olarak bazı öğrencilerin ellerinde, karşıııkı isteklerin çakışmaması nedeniyle, çok iyi değerlendirmedikleri biletler kaldı. Bu durum takas sistemi ve onunla ilgili problemleri açıklama ve paranın fonksiyonlarını gösterme fırsatı sundu. Bu nedenle dördüncü ve son rauntta piyasada değerin altında olduğundan şüphelenilen bir kaç bilet seçildi ve öğrencilere bu biletlerin bir kaç tanesi için parasal teklif yapmalarına izin verildi. Böyle bir kaç teklif isteklerin karşılıklı çakışmasını ticarette gerçekleşmesinin sınırlarını gösterdi. Deneyin sonucunda öğrenciler paranın ticaretin "fiyatını" düşürdüğünü ve sonuç olarak "talep edilen ticaretin miktarını" artırdığını gördüler.

Anderson vd.( 2008) yaptıkları çalışmada her öğrencinin bir ülkeyi temsil ettiği ve iki maldan ne kadar üreteceklerine karar verdikleri bir sınıf oyunu tasarladılar. Uygulama öğrencileri pür otarşik şartlarda üretim kararları, ülkeler arasında ticarete izin verildiğinde pür değişim kararları ve küresel bir ekonomide uzmanlaşma ve değişim kararları şeklinde üç karar alma sürecine götürdü. Deneyin başında $A$ ve $B$ ülkelerinin şarap ve peynir şeklinde iki maldan birini üretmede kullanabilmesi için her öğrenci ya da grup 4 birim emek ile donatıldı. Öğrencilere A ülkesinin ve B ülkesinin tam üretim seçenekleri listesi verildi. Liste $A$ ülkesinin göreli olarak şarap üretiminde ve $B$ ülkesinin göreli olarak peynir üretiminde daha üretken olacak şekilde yapılandırıldı. Örneğin A ülkesi tüm emeği (4 birimi) şarap üretimine tahsis ederse 26 birim şarap ve sıfır birim peynir üretebilirken tüm emeği peynir üretimine tahsis edilirse 10 birim peynir sıfır birim şarap üretmekteydi. Deneyde kullanılan iki mal tam tamamlayıcı mal olarak alındığından onların sabit oranlarda tüketilmesi gerekmiştir. Parasal olarak her ülkeye her eşleşen mal çifti için 1 \$ kazanmasına izin verildi.

Anderson vd. (2008) tarafından tasarlanan deney toplam dört aşamada (üç temel bir ek aşama) oluşmuştur. Birinci aşama otarşi aşamasıdır. Bu aşamada ilk olarak dağıtılan yönergeye göre her ülkenin, üretim teknolojisi ve Leontief tercihleri veri olduğunda, optimal emek dağılımını seçmesi istendi. İkinci aşama değişim aşamasıydı. Her ülke tek bir ticaret partnerine sahipti. Bu aşamada her ülke ekstra bir birim malını diğer ülkenin bir birimi malı karşılığında değiştirmeye izin verildi. Üçüncü aşama uzun vadeli ticaret anlaşmaları aşamasıydı. Bu aşamada ülkelerin uzun vadeli ticaret anlaşmaları içine girebilmelerine izin verildi. Ayrıca bu rauntta ticaret yapmadan önce her ülke emek gücünü farklı bir mal demeti üretmek için yeniden tahsis etmesi gerekiyordu. Bu aşamada ayrıca ülkeler üretim kapasiteleri, tercihleri ve emek donanımı ile ilgili herhangi bir bilgiyi paylaşmada serbest bırakıldılar. Bu üç aşamalı temel deneye daha sonra dördüncü bir aşama olarak ithalat ya da ihracat tarifeleri (vergiler) eklendi. Bu aşamada her ülkenin ithal ya da ihraç ettiği birim sayıları temelinde bir vergi toplanacağı duyuruldu. Birinci aşamanın (otarşi) sonucunda tüketimin her zaman 8 çift şarap ve peynir oluğu görüldü. Bu üretim ve tüketim demeti üretim imkânları eğrisi üzerinde yansıtıldı. İkinci aşamada (değişim aşaması) 1 birim peynire karşılık 1 birim şarabın (ya da tersi) değişimi ile birlikte tüketim 9 eşleşen ikiliye çıktı. Bu iki ülkenin üretimlerinde herhangi bir değişim olmasa bile ticaretten kazançlar elde ettiğini gösterdi. Üçüncü aşamada (uzmanlaşma) tüketim düzeyi $(9,9)$ dan $(14,14)$ 'e çıktı. Bu artış ülkelerin karşılaştırmalı üstünlüklere sahip malları üretmelerinin bir sonucunu, diğer bir ifade ile üretimde uzmanlaşmadan gelen kazançları, temsil etmekteydi. Dördüncü aşamada ithal edilen birim üzerinde \% 25 gibi küçük bir vergi konulduğunda sadece tüketimde bir düşmenin meydana geldiği fakat üretim sapmasının olmadığı görüldü. İthal edilen her birim başına \% 80 gibi yüksek oranlı tarife konulduğunda ise üretimin birinci aşamadaki (otarşi) düzeyine döndüğü görüldü. Fakat bu durumda ekstra çift mallardan tüketim kazancı hala pozitif olduğundan ülkeler hala bir birim peynir için bir birim şarabı takas etme imkânına sahiplerdi. Bazı farklı tarifeler sonrası öğrenciler yasaklayıcı tarife düzeyine ulaştılar. 
Son olarak Mason (2001) üretim imkânları analizinin temellerini tartıştıktan sonra karşılaştırmalı üstünlükler teorisinin alt bölümlerini öğrencilere tanıtmak ve her iki ülkenin pozisyonlarını nasıl ticaret aracılığıyla geliştirebileceklerini hem doğrusal hem de doğrusal olmayan biçimlerde göstermek için iki farklı deney gerçekleştirdi. Deneyin gerçekleştiği dersin başında sınıf iki kısma ayrıldı. Sınıfın bir tarafına ABD'yi diğer tarafına Meksika'yı temsil eden öğrenciler yerleştirildi. Deneyde ABD her birinde maksimum 10 tane kamyon (K) ya da bilgisayar (B) üretimini ifade eden doğrusal bir üretim imkânları eğrisine sahipken Meksika 9 kamyon 3 bilgisayar üretimine izin veren doğrusal bir üretim imkânlarına sahipti. Öğrencilerden ilk olarak üretim imkânları eğrisinin bu bilgilere göre çizmeleri istendi. Daha sonra her iki ülkeyi temsil eden öğrencilerden sırayla otarşi şartlarında (ticaretin olmadığı) iki mal bileşimine yönelik tercihleri, iki malın ticaret hadlerine (kamyona karşılık kaç bilgisayar ya da tersi ) yönelik tercihleri ve ticaret sonrası tüketim için mevcut olacak iki mal bileşimine yönelik tercihleri soruldu. Bu deney tasarımında ABD'de bilgisayarlar karşılığında kamyonların içsel değişim değeri $1 \mathrm{~B}=1 \mathrm{~K}$ iken Meksika'da 1B = 3K idi. İkililer bu değişim oranını keşf eder etmez doğal olarak $1 \mathrm{~B}=2 \mathrm{~K}$ karşılıkı ıayda getiren ticaret oranı varsayımına yöneldiler. Öğrenciler kısa sürede Meksika'nın kamyonda uzmanlaşarak toplam üretimini maksimize edeceğini fakat ABD'nin herhangi bir kamyon-bilgisayar kombinasyonunu ile en arzu edilen sonuca ulaşabileceğini gördüler. Deneyin sonunda Meksika'nın neden uzmanlaşması gerektiği fakat $A B D$ 'nin buna intiyacı olmadığı ve bu şartlarda ticaretin neden fayda getirdiği kısmen doğrusal üretim imkânları eğrisi özelliklerin bir sonucu olduğu açıklandı (Mason, 2001).

Mason (2001) tarafından yapılan ikinci deneyde $A B D 15,14,12,9,5,0$ bira ve $0,1,2,3,4,5$ kraker üretim kombinasyonunu gösteren bir üretim imkânları eğrisine sahipken Meksika 10, 9, 7, 4, 0 kraker ve 0,1, 2, 3, 4 bira üretim kombinasyonunu gösteren bir üretim imkânları eğrisine sahipti. ABD ve Meksika'yı temsil eden öğrencilerden bira ve kraker şeklinde iki mala yönelik üretim imkânları eğrisi çizmeleri istendi. Daha sonra öğrencilerden sırasıyla mallara yönelik içsel tercihlere ulaşmak için ticaret yapabilecekleri varsayımı ile her ülkenin ortak üretimi maksimize etmek için her bir malda kaç tane üretmesi gerektiği, mallara yönelik ticaret hadlerinin ne olduğu ve ticaret sonrası tüketim için mevcut olacağı iki mal kombinasyonu için kişisel tercihlerini yazmaları istendi.

Bu sınıf deneyinde her iki tarafın tam uzmanlaşmaya gitmesi zorunlu tutulmamış fakat her ikisinin uzmanlaşmaya doğru hareket etmesi istenilmişti.
İkinci deneyin sonucunda daha gerçekçi doğrusal olmayan üretim imkânları eğrisinin (non-linear production possibilities curve) ticari müzakere sürecini daha karmaşıklaştırdığı ve ticaret sürecinde eşitliği sağlamayı zorlaştırdığı fakat karşılaştırmalı üstünlüğe dayalı ticaretin nerdeyse tüm şartlar altında ticari partnerlerin (ülkelerin) refahını geliştirdiği görüldü (Mason, 2001).

\subsection{Döviz Kuru Deneyleri}

Döviz piyasası coğrafi olarak farklı piyasalarda meydana gelen sürekli ticaret ile belki dünyadaki en hareketli finansal piyasalardır. İşlemlerin hacmi New York Borsasının bir kaç katıdır. Üstelik bu ticaretin çok küçük bir kısmı ithalatçıların ve ihracatçıların ihtiyaçlarını karşılamak için para alıp satması ile ilgilidir (Fisher ve Kelly, 2000). Bu nedenle döviz piyasasının literatürü geniş bir teorik, ampirik ve tarihsel yönü bulunmaktadır. Buna karşın deneysel çalışmalar neredeyse yok denecek kadar az yapılmıştır (Fisher ve Kelly, 2000; Johnson, 2010).

Pedagojik açıdan baktığımızda döviz kuru iki ülke arasındaki paraların göreli fiyatlarını yansıttığından dolayı lisans öğrencileri genellikle döviz kuru kavramını anlamada güçlük çekmektedir (Mitchell vd. 2009). Öğrencilerin bu güçlüğü yenmeleri için bazı sınıf deneyleri yapılmıştır.

Mitchell vd. (2009) uluslararası iktisat derslerinde öğrencilerin döviz kurunun nasıl belirlendiğini daha iyi anlamaları ve fiyatlar ve döviz kurları arasındaki ilişki bağlamında satın alma gücü paritesi (PPP) teorisini tanımaları için bir sınıf deneyi tasarladılar. Deneyde öğrenciler iki ülkeden (Redlandia ya da Bluestan) birinin vatandaşlığını temsil ettiler. Her ülke buğday üretmekte ve buğdayın fiyatı dışsal olarak kabul edilmekteydi. Vatandaşlar başlangıçta buğday satın almak için ülkelerin parasını temsil eden 40 renkli kart ile donatıldılar. Çalışmada kırmızı kartlar Redlandia'nın parasını mavi kartlar Bluestan'ın parasını temsil ettiler. Vatandaşların burada temel amacı mümkün olduğu kadar daha fazla buğday elde etmekti. Vatandaşlar diğer ülkeden buğday satın almak istediğinde ilk olarak o ülkenin parasını uluslararası bir bankadan (deneyi yapan kişiden) satın alarak elde etmeleri gerekiyordu. Deneyde vatandaşlara her iki ülkede de buğday satın alınmasına izin verildi. Fakat Redlandia'daki satıcılar sadece kırmızı parayı Bluestan'daki satıcılar da mavi parayı kabul ediyorlardı. Önemli bir nokta vatandaşların temel amacı, nereden gelirse gelsin, mümkün olan ölçüde buğday satın almaktı. Buğday Redlandia ülkesinde iki kırmızı kartla Bluestan ülkesinde ise bir mavi kartla satın alınabiliyordu. Deneyde her vatandaşın diğer tekliflerden önce bir teklifi bağımsız bir biçimde verme gerekliliği şeklinde bir müzayede biçi- 
mi benimsenmişti. Her raunt sonrası kazanan teklifler ve anlaşılan döviz kuru herkesin görmesi için postalandı. Deneyde eğitmen denge döviz kuruna ulaşana kadar raunt yürüttü. Değerlendirme deneyinde PPP'ye ulaşma altı raunt aldı.

$\mathrm{Bu}$ değerlendirme deneyinden sonra ilave deneyler ile iç fiyatlarda meydana gelen değişmelerin denge döviz kuru üzerindeki etkisi incelendi. PPP'ye göre ülkeler karşısındaki nisbi fiyatlar döviz kurunu belirlemektedir. Bu kavramı basit bir biçimde yansıtmak amacıyla deneyde ilk olarak uluslararası fiyat sürdürülürken her ülkede buğdayın fiyatı değiştirildi. Deneyde yüksek petrol fiyatlarının yol açtığı maliyet artışı nedeniyle Redlandia'da buğday fiyatının dört kırmızı kartta Bluestan'da ise iki mavi kartta yükseldiği bildirildi. Bu deneyde öğrenciler iki ya da üç rauntta fiyatların iki ülkede orantılı olarak değişmesi durumunda PPP denge döviz kurunda hiçbir değişmenin olmadığını öğrendiler. Daha sonra deney iki ülke arasında nisbi fiyatlarda değişme meydana gelecek şekilde daha karmaşık bir hale getirildi. Nisbi fiyat değişmesi, Redlandia'daki buğday fiyatı iki kırmızı kart olarak devam ederken, Bluestan'da kötü hava koşulları nedeniyle fiyatın bir mavi karttan dört mavi kartta çıkarılması ile yapıldı. Deneyin sonucunda öğrenciler bu fiyat değişimlerinin Bluestan'ın parasının değerinde bir düşmeye ve Redlandia'nın parasının değerinde bir artışa neden olduğunu gördüler.

Mitchel vd. (2009) çalışmalarında son olarak tarifeler ya da benzeri engellerin PPP ve döviz kuru üzerindeki etkileri ve ticareti yapılmayan malların PPP'nin başarısızlığı üzerindeki rolünü ortaya koymak için deneyler yaptılar. Deneye ticaret engellerinin katılması durumunda öğrencilerin uygun döviz kurunu belirlemede zorluk çektikleri ve herhangi bir denge döviz kuruna ulaşmadıkları görüldü. Ticareti yapılmayan malları deneye eklemek için deneyi yapanlar buğday yerine kısa sürede bayatlayabilen ve bu nedenle bir ülkeden diğerine ulaştırmanın zor olduğu ve ülkede tüketilmesi gereken ekmeği koydular. Deneyin sonunda ticareti yapılmayan malların arbitraj imkânsızlığının döviz kurunun PPP'den sapmasına neden olduğu görüldü.

Hazlett ve Ganje (1999) tarafından döviz piyasasında arz ve talebin rolünü ve resmi bir döviz kurun uluslararası ticareti nasıl baskılayabileceğini ortaya koymak amacıyla bir sınıf deneyi yapıldı. Deneyde Whit olarak adlandırılan bir ülkede yaşayan vatandaşların Whittie parasını kullandıkları varsayıldı. Sınıfın yarısı ABD'ye mal satan ihracatçıları yarısı da ABD'den mal satın alan ithalatçıları temsil edecek şekilde ayarlandı. Her bir ihraçatçı her periyodun başında $100 \$$ karşıı̆ğında ABD'ye bir mal satabilmekteydi. İhracatçı- lar Dolarlarını Whittie ile değiştirmekte ve bu nedenle döviz piyasasında Dolar satıcısı konumundaydılar. İthalatçılar ise 100 \$ karşılığında ABD'den bir mal satın alabilmekteydiler. Bu satın alım için Dolara ihtiyacı olduğundan ithalatçılar döviz piyasasında Dolar alıcısı konumundaydılar. Deneyci hükümet temsilcisi olarak hizmet etmekte ve deneyin başında Doların alışsatışında geçerli resmi döviz kurunu bildirmekteydi. Hükümet aşırı değerli parayı sürdürmek istediğinden deneyci Dolar başına serbest döviz piyasasında ortaya çıkan kurdan daha az Whittie gelecek şekilde bir kur belirlemekteydi.

Deney dört farklı aşamada oluşacak şekilde tasarlandı. Birinci aşama; her bir ihracatçının bir malı satıp satmayacağına karar verdiği aşamaydı. Eğer bir ihracatçı malı satmamaya karar vermesi duurumunda o periyotta daha ileri bir eyleme sahip olmayacaktı. İkinci aşamada; hükümet temsilcisi resmi kurda herhangi bir ithalatçının Dolar satın alma ya da herhangi bir ihracatçının Dolar satma arzusunun olup olmadığını sordu. Üçüncü aşamada; hükümet temsilcisi, hükümette satması gereken 100 \$'a sahip olduklarını ortaya çıkarma sürecinde, bir kaç ihracatçıyı kayıtlarını kontrol etmek için rassal olarak seçti. Burada her ithalatçı resmi kurda Dolar satın almak istese de hükümet aşırı talebi karşılayacak kendi Dolar rezervlerine sahip değildi. Bunun yerine ihracatçıdan aldığı Doları satın alacak ithalatçıları rassal olarak seçme yoluna gitti. Bununla deneyin hükümet boyutu kapanmış oldu. Dördüncü aşamada; paralel piyasa çift taraflı sözlü müzayede olarak deneye dahil edildi. Bunun için resmi kurda ticaret yapmayan öğrenciler sınıf merkezinde toplandılar. Burada ithalatçılar 100 \$ elde etmek için ödeyecekleri Whittie sayısını ve bir mal satan ihracatçılar 100 \$ için kabul edecekleri Whittie sayısını yüksek sesle bildirdiler. Bir ihracatçı ile bir ithalatçı bir fiyat üzerinde anlaştıklarında tahtadaki bir kayıt görevlisine bunu söyleyip piyasadan çıkıyorlardı. Ticaret süreci ticaret yapmaya istekli tüm kişilerin onu gereçekleştirmesine kadar devam etti. Daha sonra 100 \$ elde etmiş olan ithalatçıların yabancı malı satın almasıyla periyot sona eriyordu. Arkasından yeni bir periyota geçildi. Hükümetin paralel piyasada ticareti cezalandırmadığı bir kaç periyottan sonra, deneyci hükümetin paralel piyasada döviz ticaretini sonlandırmaya karar verdiğini duyurdu. Paralel piyasanın içine cezanın girmesi onu bir gri piyasadan (gray market) kara borsa (black market) piyasasına dönüştürdü. Her kara borsa tüccarı yüzde 50 yakalama olasılığına ve Whittie olarak bir ceza ödemesine sahipti. Hükümetin bu periyotta kara borsa ticareti yapanları yakalayıp yakalamadığı bir yazı tura ile belirlendi. 
Hazlett ve Ganje (1999) bu şekilde tasarladıkları deneyi iki farklı derste uyguladı. Birinci grup öğrenciye aşırı değerli resmi kurdan ticaret yapabilen ithalatçılardan olmanın avantajları ve ona zorlanan ihracatçılardan olmanın dezavantajları açık biçimde gösterildi. Deneyin her periyodunda resmi bir döviz kurunun varlığı durumunda bazı yüksek maliyetli ihracatçıların, Dolar gelirlerini hükümete satmaya zorlanmaları durumunda yaşayacakları kayıplar korkusu nedeniyle, ihracat yapmayı bıraktıkları görüldü. Dolar satan az sayıda ihracatçı ile çok az sayıdaki ithalatçı, serbest bir piyasada meydana gelenden daha düşük uluslararası ticaret ile sonuçlanan, Dolar elde edebildi. Başka bir sınıfa uygulanan ikinci deney 14 periyottan oluştu. Burada deneyin 7-14. periyotlarında paralel piyasada ticaret üzerinde bir ceza getirildi. Deneyin sonucunda uluslararası ticarettin gri piyasada değil kara borsada baskı altına alındığı görüldü. Hem Dolar alıcıları hem de Dolar satıcılarının cezalandırıması ile kara borsada arz ve talebin gri piyasaya göre düştüğü görüldü. Gri bir piyasada döviz kurunun serbest döviz kuru piyasasındaki denge oranına aşağı yukarı uyduğu görüldü. Fakat kara borsada döviz kuru bu piyasada ticaret yaparken yakalanmaya konulan ceza riskini yansitacak şekilde oluştu. Bu nedenle gri piyasa kuru serbest piyasa değerine yaklaşırken kara borsa fiyatında böyle bir durum söz konusu olmadı. Kara borsa kurları her periyotta 2.40 ya da yukarı bir ortalamada olurken gri piyasa döviz kuru her periyotta 2.30 ya da aşağı bir ortalamada oldu.

Fisher ve Kely (2000) tarafından yapılan başka bir çalışmada deneklerin iki farklı varlığı alıp sattığı deneysel piyasalar analiz edildi. Deneyde varlıkların özellikleri deney boyunca değiştirildi ve döviz kuru, varlıkların nisbi fiyatı olarak alındı. Çalışmada döviz kurları ile ilgili hipotezler üç kategoride incelendi. Birincisi; zaman içinde arbitraj, ikincisi; varlıklar ile ilgili arbitraj, üçüncüsü; deneklerin risk alma tutumları ve onların tahmin etme yetenekleri oldu.

Deney tasarlanırken dalgalı döviz kurunun durağan olmayan doğasını yansıtan bir piyasa oluşturuldu. Deneyin önemli bir özelliği döviz piyasasında tüccarların çapraz kur arbitrajı ile karşı karşıya olması nedeniyle iki varlığın ticaretinde eş anlılığın olmasıydı. Her seans eş anlı olarak ticareti yapılan mavi ve kırmızı şeklinde iki varlık piyasasından oluşmaktaydı. Ticaret başına en azında bir mavi varlık ve bir kırmızı varlık şeklinde sabit bir arz vardı. Piyasalar sözlü çift müzayede olarak el ile yürütüldü. Her seans 15 periyottan oluştu ve karlar (elde edilen para) her periyodun sonunda ödendi. Periyotlar 6 dakika sürdü.

Yazarların çalışmada ileri sürdükleri temel fikir döviz piyasalarındaki tüm ticaretin arbitrajcıların faiz oranlarındaki ya da merkez bankalarının müdahalelerindeki dışsal değişikliklere yönelik birbirlerinin ticaret stratejilerine karşı kısa dönem reaksiyonları konusundaki bekleyişlerine dayanmasıydı. Bu nedenle tüccarların birbirlerinin dışsal varlık fiyatlandırması konusunda belirsizlik ile karşı karşıya kaldıkları bir deney döviz piyasasını oldukça iyi yansıtacaktı.

Ajanlara ilk olarak bu varlıkların ve Dolarların farkIı birleşimlerinden meydana gelen donatımlar (endowment) verildi. Ajanların donatımlarının beklenen değerleri eşitti. Her periyodun başında deneyci hem mavi hem de kırmızı bir varlık için maksimum, minimum ve beklenen değeri bildiriyordu. Bu rakamlar ve geçmiş karlar aynı zamanda tahtada gösteriliyordu.

Deney altı tasarım şeklinde uygulandı. Birinci tasarımda başlangıç donatımları itibariyle birbirinden farklı altı tüccar vardı. Mavi ve kırmızı varlığın karı dört farklı katkı ( $0 \$, 0.4 \$, 0.14 \$$ ve 0.30 \$) getiren ve her biri $1 / 4$ olasılıkla meydana gelen rassal değişkenlerdi. Bu tasarımda mavi ve kırmızı varlık arasında bir fark yoktu.

İkinci tasarımda mavi ve kırmızı varlıklar arasında gerçek bir fark yaratıldı. Burada sabit döviz kuru rejimini yansıtacak şekilde varlıklar arasındaki fark tam ilişkili olarak tasarlandı. Örneğin, mavi varlık 0.60 \$ verdiğinde kırmızı varlık 0.30 \$ vermekteydi, ya da mavi varlık 0.8 \$ verdiğinde kırmızı varlık 0.4 \$ vermekteydi. Üçüncü tasarım ikincisi ile benzerdi fakat bu sefer kar payı bağımsız biçimde dağıtıldı. Örneğin, mavi varlık 0.60 \$ verdiğinde kırmızı varlık dört katkıdan $(0 \$, 0.4$ \$, 0.14 \$, 0.30 \$) birini verebilirdi. Bu tasarım, her iki varlığı açık bir pozisyonda tutmada gelen beklenen kazanç aynı olduğundan, dalgalı döviz kuru piyasasında, açık faiz paritesini açıklamak için yapıldı.

Dördüncü ve beşinci tasarımda katkıları sadece iki unsur olan ve $1 / 2$ olasılıkla meydana gelen kar payları kullanıdı. Riskli olan mavi varlığın katkısı ( $0 \$$ ve 0.50 \$) iken güvenli olan kırmızı varlığın katkısı ( 0.20 \$ ve 0.30 \$) şeklindeydi. Bu tasarımlar döviz kuru piyasasında risk primini açıklamak için tasarlandı ve birbirine benzerdi. Sadece beşinci tasarımda deneklere periyot sonu döviz kuru tahminleri soruldu ve en iyi tahminciye seansın sonunda ekstra bir Dolar kazanma imkanı verildi. Burada döviz kuru kırmızı varlığın fiyatının mavi varlığın fiyatına bölümü olarak alındı. Altınc tasarım birinci ile aynı olup sadece bir hafta boyunca aynı grup tüccar ile üç seans tekrar edildi. Amaç aynı grup tüccarın kullanımının iki varlıklı piyasada balonları azaltıp azaltmadığını görmekti.

Deneyin sonunda her iki piyasada balonların meydana geldiği ve mavi ve kırmızı piyasada oluşan balonların birbiriyle pozitif ilişkili olduğu görüldü. Deneyde elde edilen veriler güçlü spekülatif unsurlara 
sahip piyasalarda rasyonel davranışın geçerli olduğu, deneklerin riskli varlıklara yönelik hafif tercihte bulundukları ve davranışlarının ticaret yaptıkları varlık piyasaları üzerinde etkilere sahip olduğunu algılayabildiklerini gösterdi. Yazarlar çalışmalarında döviz kuru piyasasında bulaşma etkisine (contagion effect) yönelik kanıtlar da elde ettiler. Yazarlara göre bir varlık piyasasında bir balonun patlaması tüm piyasalardaki ajanların temel para konusundaki inançlarını radikal biçimde güncelleştirmektedir. Çalışmada son olarak deneklerin döviz kurlarını tahmin etmede iyi performans gösterdikleri görüldü. Deneklerin özellikle diğerlerinin ticaret stratejileri konusunda bir belirsizliğin varlık fiyatları üzerinde egemen bir etkiye sahip olduğu piyasalarda oldukça iyi tahminlerde bulundukları görüldü.

\section{SONUÇ}

İktisatta ilk sınıf deneyleri Chamberlin (1948) tarafından yapılsa da sınıf deneylerine yönelik ilgi 1990 'larda artmıştır. Bunda iki önemli faktör etkili olmuştur. Birincisi deneysel iktisatçıların sayısındaki artış ikincisi geleneksel ders verme biçimindeki memnuniyetsizliktir. İktisadın oldukça soyut ve teori ağırlıklı olması beraberinde öğrencilerin konuları anlamasında zorluklar getirmiştir. Deneysel iktisatçılar öğrencilerin kitaplardaki teorik bilgiyi, uygulamada daha iyi görmeleri için sınıf deneyleri yapma yoluna gitmişlerdir.

Gerçekten yapılan çalışmalar sınıf deneylerinin ders zamanını alması, ekstra hazırlama zamanı gerektirmesi, öğrencilere para gibi teşvik vermeyi gerektirmesi gibi bazı maliyetlerine rağmen önemli faydaları olduğunu göstermiştir. Sınıf deneylerinin en önemli faydası öğrencilerin ekonomik karar vericiler rolüne girerek teorik bilgileri uygulamalı olarak öğrenmeleridir. Yapılan karşılaştırmalı çalışmalar da öğrencilerin geleneksel ders yönteminin aksine deneysel ya da aktif öğrenme ile iktisat konularını daha iyi öğrendikleri görülmüştür. Sınıf deneylerinin diğer önemli faydaları arasında öğrencilerin sınıf deneylerine aktif olarak katılmaktan zevk almaları ve bunun öğretene olan tutumlarında pozitif etki yaratması, öğretenlerin deneyleri kullanmakta zevk alması, deney sonrası tartışma soruları ile öğrencilerin konuları derinlemesine tartışmaları ve kendi kararlarının teori ile tutarlı olup olmadığını görebilmesi bulunmaktadır.

Sınıf deneylerinin uygulamada gittikçe artmasına ve faydalarının görülmesine karşın bazı tartışma konuları da bulunmaktadır. Bunlar sınıf deneyinin yapıldığı sınıftaki öğrenci sayısının kaç olması gerektiği, sınıf deneyi için en uygun zamanın ne olduğu, öğrencilerin deneye katılmasından dolayı ne tür teşviklerin verilmesi gerektiğidir.

Sınıf deneylerinin iktisat uygulamalarına baktığımızda daha çok piyasa denge konularının işlendiği mikro iktisat ağırlıklı oldukları görülür. Bu nedenle uluslararası iktisat konularını sınıf deneyleri ile ele alan çalışmalar oldukça azdır. Yapılan sınıf deneyleri daha çok öğrencilere karşılaştırmalı üstünlükler kavramını ve uzmanlaşma ve ticaretin değerini anlamada yardım etmek için tasarlanmıştır. Bu deneylere ilave olarak öğrencilerin genellikle anlamada güçlük çektikleri döviz kuru kavramına yönelik sınıf deneyleri de yapılmıştır. Bu sınıf deneyleri ile öğrenciler temel uluslararası iktisat kavramlarının gerçek dünyada nasıl işlediğini görme imkânı elde etmişlerdir.

Deneylerin ortaya koyduğu önemli bir sonuç da, öğrencilerin sahaya sürülerek, öğrendikleri teoriye paralel pratiğin içinde olmalarını temin etmek gerektiğidir. Teori sınıflarının kalabalıklığı hem deneyleri zorlaştırmakta hem de sahaya sürülen öğrencilerin bilgiyi ne kadar içselleştirdiğini denetlemeyi zora sokmaktadır. Üniversitelerin de ilgili kavramların bu amaçla yeni kurumsal ilişkiler ağı oluşturmaları gerektiği açıktır.

Sonuç olarak iktisat ve bu bağlamda uluslararası iktisat genellikle bazı öğrencilere temel önsezileri kazanmaktan alı koyabilecek düzeyde soyut öğretilmektedir. Fakat dersler ve kitaplar öğrencilerin kararlar aldığı ve etkileşimde bulunduğu sınıf uygulamaları ile tamamlanabilir. Bu yaklaşım öğrencilerin iktisat derslerine olan ilgisini artırabilir ve şüpheleri azaltabilir. 


\section{KAYNAKLAR}

Anderson, L. R., Blanchard, E., Chaston, K., Holt, C., Razzolini, L. ve Singleton, R. (2008) "Production and gains from trade" Perspectives in Economic Education Research, 4 (1): 3-22.

Bastian, C. T., Menkhaus, D. J. ve Yakunina, A. V. (1996) " Experimental Economics In The Classroom: Reinforcing Selected Concepts Related To Consumer Demand" NACTA Journal, 40 (2): 12-14.

Bergstrom, T. ve Miller, J. H. (2000) Experiments With Economic Principles: Microeconomics,2nd Edition, New York, McGraw-Hill.

Brauer, J. (1998) "A Saving/Consumption Game for Introductory Macroeconomics" Classroom Expernomics, 7 (1): 10-13.

Brauer, J. ve Delemeester, G. (2001) “Games Economists Play: A Survey of Non-Computerized Classroom Games For Economics” Journal of Economic Surveys, 15 (2): 221-236.

Chamberlin, E. H. (1948) "An Experimental Imperfect Market" Journal of Political Economy, 56 (2): 95-108.

Chiang, E. P. (2007) "Asymmetric Information, Bargaining, And Comparative Advantage In Trade Relationships: An Interactive Game" Southern Economic Journal, 74 (2): 601-608.

DeYoung, R. (1993) "Market Experiments: The Laboratory Versus The Classroom" Journal of Economic Education, 24 (4): 335-351.

Dickie, M. (2006) "Do Classroom Experiments Increase Learning In Introductory Microeconomics?" Journal of Economic Education, 37(3): 267-288.

Durham, Y., McKinnon, T. ve Schulman, C. (2007) "Classroom Experiments: Not Just Fun and Games" Economic Inquiry, 45 (1):162-178.

Emerson, T. ve Hazlett, D. (2012) "Classroom Experiments" Hoyt ve McGoldrick (eds) International Handbook on Teaching and Learning Economics, London, Edward Elgar Publishing Limited.

Emerson, T. L.N. ve Taylor, B. A. (2004) "Comparing Student Achievement Across Experimental and LectureOriented Sections of A Principles of Microeconomics Course" Southern Economic Journal, 70 (3): 672-693.

Fisher, E. O. ve Kelly, F. S. (2000) "Experimental Foreign Exchange Markets" Pacific Economic Review, 5 (3): 365-388.

Frank, B. (1997) "The Impact of Classroom Experiments on The Learning of Economics: An Empirical Investigation" Economic Inquiry, 35 (4): 763-769.

Gremmen, H. ve Potters, J. (1997) "Assessing The Efficacy of Gaming in Economic Education" Journal of Economic Education, 28 (4): 291-303.

Haupert, M. J. (1996) "An Experiment in Comparative Advantage" Journal of Economic Education, 27 (1): $37-44$
Hazlett, D. (1997) "Teaching Tools: A Common Property Experiment with A Renewable Resource" Economic Inquiry, 35 (4): 858-861.

Hazlett, D. ve Ganje, J. (1999) "An Experiment with Official and Parallel Foreign Exchange Markets in A Developing Country" Journal of Economic Education, 30(4): 392-401.

Holt, C. A. (1999) "Teaching Economics with Classroom Experiments" Southern Economic Journal, 65 (3): 603-610.

Holt, C. A. , Tanga, M. ve W. B. Walstad (1998) "Experimental Economics in the Classroom" Walstad ve P. Saunders (eds) Teaching Undergraduate Economics: A Handbook for Instructors, New York, McGraw Hill.

Houston, R. G. Jr. ve Hoyt, G. M. (2001) "International Trade and Money: A Simple Classroom Demonstration" Classroom Expernomics, 10 (1): 31-35.

Johnson, P. (2010) "An International Economics Classroom Experiment" Southern Economic Journal, 77 (2): 501-513.

King, H. B. (1999) “A Neophyte's Cost-Benefit Analysis of Classroom Experiments and Simulations in Introductory Economics" Department of Economics, University of Regina Discussion paper No: 79.

Mason, P. M. (2001) "Representative Templates and Methodology for Stodder's Comparative Advantage Experiments" Classroom Expernomics, 10 (1): 9-12.

Mitchell, D., Rebelein, R., Schneider, P. H. H., Simpson, N. ve Fisher, E. O. (2009) "A Classroom Experiment on Exchange Rate Determination with Purchasing Power Parity” Journal of Economic Education, 40 (2): 150-165.

Noussair, C. ve Walker, J. (1998) "Student Decision Making as Active Learning: Experimental Economics in the Classroom" W. Becker ve M.Watts (eds) Teaching Economics to Undergraduates: Alternatives to Chalk and Talk, Northampton MA, Edward Elgar.

Ortmann, A. ve Colander, D. (1997) "A Simple Principal-Agent Experiment for the Classroom" Economic Inquiry, 35 (2): 443-450.

Parker, J. (1995) "Using Laboratory Experiments To Teach Introductory Economics" Reed College Working Paper, http://academic.reed.edu/economics/faculty/parker/exp.html $(13,10.2014)$.

Stodder, J. (1994) "A Simple Experiment of Comparative Advantage" Classroom Expernomics, 3(1): 8-10. 
